\title{
BMJ Open Profile and complexity of travel medicine consultations in Chile: unicentric cross-sectional study
}

\author{
Thomas Weitzel (iD) ${ }^{1,2}$
}

To cite: Weitzel T. Profile and complexity of travel medicine consultations in Chile: unicentric cross-sectional study. BMJ Open 2020;10:e037903. doi:10.1136/ bmjopen-2020-037903

- Prepublication history for this paper is available online. To view these files, please visit the journal online (http://dx.doi. org/10.1136/bmjopen-2020037903).

Received 20 February 2020 Revised 14 July 2020

Accepted 06 August 2020
Check for updates

(c) Author(s) (or their employer(s)) 2020. Re-use permitted under CC BY-NC. No commercial re-use. See rights and permissions. Published by BMJ.

${ }^{1}$ Programa Medicina del Viajero, Clinica Alemana, Facultad de Medicina Clínica Alemana, Universidad del Desarrollo, Santiago, Chile

${ }^{2}$ Instituto de Ciencias e Innovación en Medicina (ICIM), Facultad de Medicina Clínica Alemana, Universidad del Desarrollo, Santiago, Chile

Correspondence to Dr Thomas Weitzel; thomas.weitzel@gmail.com

\section{ABSTRACT}

Objective To analyse the spectrum, vaccination needs and pretravel advice complexity of travellers presenting at a travel medicine clinic in Santiago, Chile.

Design Cross-sectional study.

Setting Pretravel consultations in a private healthcare centre in Chile, an 'emerging market' country in South America.

Participants Travellers $(n=1341)$ seeking pretravel advice at the Travel Medicine Program of Clínica Alemana, Santiago, from April 2016 to March 2018.

\section{Primary and secondary outcome}

measures Demographical and travel characteristics, indications for travel vaccines and malaria prophylaxis, and complexity of travel consultations.

Results of 1341 travellers, $51 \%$ were female; the median age was 33 years. Most frequent travel reasons were tourism $(67 \%)$ and business $(20 \%)$. Median travel duration and time to departure were 21 days and 28 days, respectively. Most destinations were located in America (41\%), followed by Asia (36\%) and Africa (26\%); $96 \%$ visited less developed countries, mostly in tropical regions, with risk of arboviral infections (94\%) and malaria (69\%). The indicated vaccine indications comprised hepatitis A (84\%), yellow fever (58\%), typhoid fever (51\%), rabies $(29 \%)$, polio (8\%), Japanese encephalitis $(6 \%)$ and meningococcal meningitis (5\%). More than $60 \%$ of consultations were classified as complex.

Conclusion The studied population mostly visited less developed tropical regions, resulting in a high requirement of yellow fever and other travel-related vaccinations. Most consultations were complex and required a comprehensive knowledge and training in travel medicine.

\section{INTRODUCTION}

Travel medicine was created as a new discipline in the 1970s due to the growing interest in illnesses of European and North American travellers. ${ }^{1}$ Since then, the body of knowledge and practical experience of travel medicine almost exclusively addresses the needs of those travelling from industrialised countries to less developed regions. Due to the growing economic power of 'emerging economies', however, the extent of international travel from underdeveloped regions has already surpassed the industrialised nations. ${ }^{23}$ Travel medicine is, therefore, an emerging topic in

\section{Strengths and limitations of this study}

The study provides one of the largest datasets on pretravel consultations from a less developed country.

- The study collected standardised data over a period of 24 months.

- All included travellers were evaluated by a single travel medicine expert, which improves data homogeneity.

- A limitation is that the study was conducted in a single centre.

many countries in Latin America, Asia and Africa, and international experts have called for action to 'close the gap in medicine'. 34

A limited number of studies have analysed the characteristic of travellers receiving pretravel consultations in travel medicine centres, almost all from industrialised countries. $^{5-10}$ Similar data from less developed nations are almost absent. In South America, the only published data derive from population of 445 travellers attended at a travel clinic in Sao Paulo, Brazil, from 2003 to 2006. ${ }^{11}$ The presented study analysed the profile, vaccination needs and complexity of travellers counselled over a 24-month period in a Travel Medicine Programme in Santiago, Chile, to gain a better understanding of the needs and challenges of travel medicine in South America.

\section{METHODS}

The study was conducted in the Travel Medicine Programme of Clínica Alemana, a private healthcare centre in Santiago, Chile. The characteristics of consecutive pretravel consultations at the travel clinic were recorded in an anonymised manner from April 2016 to March 2018. Data were collected using a standardised spreadsheet (MS Excel 2010). Demographic information included sex, age and nationality. Destinations were registered 
as regions according United Nations M49 Standard ${ }^{12}$ and not as individual countries. Trips including multiple regions or travel reasons were counted separately. For each traveller, the indications for travel-related vaccinations and malaria prevention were recorded according to international guidelines, independent of whether the respective person already had the vaccine. Epidemiological information regarding yellow fever (YF) and other infections as well as requirements for YF, polio and meningococcal vaccines based on information from WHO (www.who.int/ith) and Shoreland Travax (www. shoreland.com/services/travax). Other travel vaccines were indicated in accordance to recommendations by the World Health Organization (WHO), Centers for Disease Control and Prevention (CDC), Infectious Diseases Society of America and the German Society of Tropical Medicine. ${ }^{13-15}$ The indication for rabies vaccine, for example, was travel of $\geq 4$ weeks to regions with terrestrial rabies but insufficient access to postexposure prophylaxis (including HRIG) (or shorter travel with high risk of exposure). Measles vaccine was indicated according to the Chilean Ministry of Health. ${ }^{16}$ Malaria prevention measures mainly followed the German/Swiss and UK recommendations. ${ }^{1718}$

As an additional tool to describe the population of travellers of our centre, we created a scoring system classifying the complexity of each consultation (table 1). This classification included criteria related to the traveller, the individual trip, the timing of the consultation and problems regarding YF vaccination. Consultations with a score of 1 were classified as 'complex' and with scores $>1$ as 'very complex'.

Demographic and travel-associated characteristics of leisure and work-related travellers were compared using VassarStats (http://vassarstats.net). Categorical variables were tested by $\chi^{2}$ test; $p$ values $<0.05$ were considered statistically significant. Continuous variables were described by median and IQR (calculated by QUARTILE. INC function, MS Excel 2010) and compared by MannWhitney U test.

Since demographical and clinical data were collected anonymously and travel-related data were categorised without recording exact destinations, the need for informed consent was waived.

\section{RESULTS}

During the study period of 24 months, 1341 consecutive pretravel consultations were included. Travel advice was provided by a single physician. The mean monthly number of consultations was 55; ranging from 36 in September to 99 in January.

\section{Travellers' demographics}

Slightly more than half of travellers were female (51.0\%). The median age was 33 years (IQR 26-46 years; range, 3 months to 82 years). More than $90 \%$ were adults, most of them $(80.3 \%)$ aged $18-59$ years; $6.3 \%$ were $60-69$ year
Table 1 Complexity score of pretravel consultations based on different parameters related to the individual traveller and his planned trip

\begin{tabular}{|c|c|c|c|}
\hline \multicolumn{3}{|c|}{ Parameter } & Points \\
\hline \multicolumn{4}{|c|}{ Traveller } \\
\hline & \multicolumn{2}{|c|}{$\begin{array}{l}\text { Pregnancy-related }{ }^{\star} / \text { breastfeeding OR } \\
\text { Immunocompromised OR } \\
\text { Other risk factors } †\end{array}$} & 1 \\
\hline \multicolumn{4}{|c|}{ Travel } \\
\hline & \multicolumn{2}{|l|}{ VFR OR } & 1 \\
\hline & \multicolumn{3}{|c|}{ Adventure travel OR } \\
\hline & \multicolumn{3}{|c|}{ Other risk factors $\ddagger$} \\
\hline & $\begin{array}{l}\text { Duration } \geq 4 \\
\text { weeks OR }\end{array}$ & $\begin{array}{l}\text { AND less developed } \\
\text { region }\end{array}$ & 1 \\
\hline & \multicolumn{3}{|l|}{ Frequent trips } \\
\hline & \multicolumn{2}{|c|}{ Visiting $\geq 3$ regions } & 1 \\
\hline \multicolumn{4}{|c|}{ Time to departure } \\
\hline & \multicolumn{2}{|l|}{$<2$ weeks OR } & 1 \\
\hline & $<4$ weeks & $\begin{array}{l}\text { AND less developed } \\
\text { region for } \geq 4 \text { weeks }\end{array}$ & \\
\hline \multicolumn{4}{|c|}{ Yellow fever (YF) } \\
\hline- & \multirow[t]{3}{*}{$\begin{array}{l}\text { Vaccination } \\
\text { indicated }\end{array}$} & $\begin{array}{l}\text { AND time until travel } \\
<10 \text { days }\end{array}$ & 1 \\
\hline- & & AND age $\geq 60$ years & 1 \\
\hline- & & $\begin{array}{l}\text { AND other YF } \\
\text { vaccine-related } \\
\text { problem§ }\end{array}$ & 1 \\
\hline
\end{tabular}

*Traveller or partner of traveller is pregnant or intends to get pregnant.

†Severe disease or disability.

†Higher-than-average risk of exposure to contaminated water/ food, vectors, animals or local population or risk of greater impact of disease.

§Contraindication for YF vaccine or vaccine temporarily not available.

VFR, visiting friends and relative.

of age and $4.0 \%$ were $\geq 70$ years. Children ( $<10$ years) accounted for $4.3 \%$ of individuals; $0.6 \%$ were $<2$ years and $5.1 \%$ were $10-17$ years old (table 2). Most travellers $(84.2 \%)$ were of Chilean nationality. Foreign individuals attending our programme travelled for leisure $(65.6 \%)$, work $(30.2 \%)$ or were visiting friends and relatives (VFRs) $(10.4 \%)$; the majority originated from other Latin American countries or from Europe (table 2).

\section{Travel characteristics}

Tourism was the most frequent travel purpose $(66.6 \%)$, followed by business (19.9\%), backpacking (11.5\%), adventure travel $(5.8 \%)$ and VFR (4.8\%) (table 2). Among tourists, $12.2 \%$ were on honeymoon and $4.1 \%$ planned a cruise ship tour.

The median travel duration was 21 days (ICR 11-28 days; range 1 day to 6 years). Most trips lasted 15-28 days (37\%), followed by $8-14$ days (25.3\%); $22.2 \%$ of journeys 
Table 2 Demographic features and travel-related characteristics of all pretravel consultations

\begin{tabular}{|c|c|c|}
\hline Characteristics & & $\begin{array}{l}\text { All travellers } \\
(\mathrm{n}=1341)\end{array}$ \\
\hline \multirow[t]{2}{*}{ Sex } & Male & $657(49.0)$ \\
\hline & Female & $684(51.0)$ \\
\hline \multirow[t]{7}{*}{ Age } & Median & 33 years \\
\hline & IQR & $26-46$ years \\
\hline & Range & $0-82$ years \\
\hline & $<10$ years & $58(4.3)$ \\
\hline & $10-17$ years & $68(5.1)$ \\
\hline & $18-59$ years & 1077 (80.3) \\
\hline & $\geq 60$ years & $138(10.3)$ \\
\hline \multirow[t]{6}{*}{ Nationality } & Chile & $1129(84.2)$ \\
\hline & Non-Chilean & $212(15.8)$ \\
\hline & Latin America & $87(6.5)$ \\
\hline & Europe & $75(5.6)$ \\
\hline & North America & $25(1.9)$ \\
\hline & Other & $25(1.9)$ \\
\hline \multirow[t]{10}{*}{ Travel reason } & Leisure & $1021(76.1)$ \\
\hline & Tourism & $893(66.6)$ \\
\hline & Backpacking & $154(11.5)$ \\
\hline & Adventure travel & $78(5.8)$ \\
\hline & Work related & $311(23.2)$ \\
\hline & Business & 267 (19.9) \\
\hline & Study & $46(3.4)$ \\
\hline & Others & $72(5.4)$ \\
\hline & VFR & $64(4.8)$ \\
\hline & Pilgrimage & $8(0.6)$ \\
\hline \multirow{8}{*}{ Travel duration } & Median & 21 days \\
\hline & IQR & 93.1 days \\
\hline & Range & $\begin{array}{l}1 \text { day- } 6 \\
\text { years }\end{array}$ \\
\hline & $1-7$ days & 208 (15.5) \\
\hline & 8-14 days & $338(25.3)$ \\
\hline & $15-28$ days & 495 (37.0) \\
\hline & 29-90 days & 115 (8.6) \\
\hline & $>90$ days & $182(13.6)$ \\
\hline \multirow[t]{6}{*}{ Time to departure } & Median & 28 days \\
\hline & IQR & 14-49 days \\
\hline & Range & $0-220$ days \\
\hline & $0-13$ days & $311(23.2)$ \\
\hline & 14-27 days & $343(25.6)$ \\
\hline & $\geq 28$ days & 666 (49.7) \\
\hline \multirow[t]{4}{*}{ Destinations } & America & $544(40.6)$ \\
\hline & Asia & 477 (35.6) \\
\hline & Africa & 352 (26.2) \\
\hline & Oceania & $66(4.9)$ \\
\hline
\end{tabular}

Continued
Table 2 Continued

\section{Characteristics}

All travellers ( $n=1341)$

\begin{tabular}{|c|c|c|}
\hline & Europe & $64(4.8)$ \\
\hline & $\begin{array}{l}\text { Less developed } \\
\text { regions* }\end{array}$ & $1284(95.7)$ \\
\hline & 1 region* visited & $984(73.4)$ \\
\hline & 2 regions ${ }^{\star}$ visited & $277(20.7)$ \\
\hline & $\geq 3$ regions* visited & $80(6.0)$ \\
\hline \multirow[t]{3}{*}{ Infection risk } & $\begin{array}{l}\text { Dengue (tropical } \\
\text { arboviruses) }\end{array}$ & $1261(94.0)$ \\
\hline & Malaria & $926(69.1)$ \\
\hline & Yellow fever & $502(37.4)$ \\
\hline \multirow[t]{11}{*}{ Indicated vaccines } & Hepatitis A & $1124(83.8)$ \\
\hline & Yellow fevert & $771(57.5)$ \\
\hline & Visiting endemic region & $411(30.6)$ \\
\hline & Entry requirement & $373(27.8)$ \\
\hline & Waiver letter & $70(5.2)$ \\
\hline & Typhoid fever & $682(50.9)$ \\
\hline & Rabies & $382(28.5)$ \\
\hline & Measles & $280(20.9)$ \\
\hline & Polio & $103(7.7)$ \\
\hline & Japanese encephalitis & $86(6.4)$ \\
\hline & Meningococcal & $68(5.1)$ \\
\hline \multirow[t]{3}{*}{ Malaria prevention } & Chemoprophylaxis & $375(28.0)$ \\
\hline & $\begin{array}{l}\text { Stand-by emergency } \\
\text { treatment }\end{array}$ & $164(12.2)$ \\
\hline & $\begin{array}{l}\text { Mosquito prevention } \\
\text { only }\end{array}$ & 387 (28.9) \\
\hline
\end{tabular}

Values represent number (\%) of consultations, if not otherwise specified.

${ }^{*}$ According to United Nations classification. ${ }^{12}$

†Indication for vaccine or waiver letter.

VFR, visiting friends and relatives.

were longer than 4 weeks and $13.6 \%$ exceeded 3 months (table 2). Repeated travel activities were reported by $6.3 \%$ of individuals, most of them $(82 \%)$ for work reasons. The median time to departure was 28 days (ICR 14-49 days; range 0-220 days), that is, about half presented less than 4 weeks prior to travel. In $23.2 \%$, there was less than 2 weeks to departure (table 2).

As shown in figure 1, the spectrum of visited regions was wide. The vast majority $(95.7 \%)$ of trips included itineraries in less developed regions, mostly in Latin America and the Caribbean (LAC) (37.0\%), South East/South Central Asia (33.0\%) and sub-Saharan Africa (25.1\%). About $40 \%$ of planned trips included American countries, mostly in South America (table 2, figure 1). Still, more than $70 \%$ of trips were intercontinental, predominantly to Asia and Africa (table 2). The median duration was shorter in journeys to LAC (10 days; IQR 7-16) than 


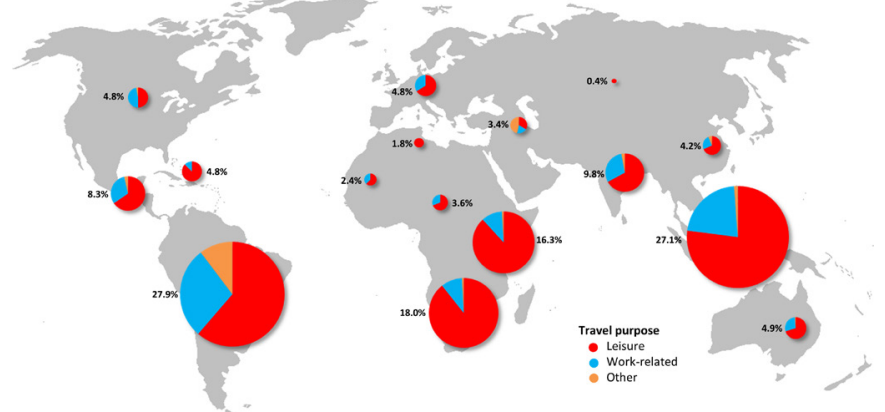

Figure 1 Distribution (\%) of visited regions among 1341 pretravel consultations (diameters of circles are proportional to percentage). MAP source: public domain, https:// commons. wikimedia.org/w/index. php?curid=868126.

to South East/South Central Asia (28 days; IQR 21-90) and to sub-Saharan Africa (18 days; IQR 14-21).

Regarding the risk of tropical infections, $94.0 \%$ were at risk for dengue or other tropical arboviral infections, and $69.1 \%$ and $37.4 \%$ visited regions endemic for malaria and YF, respectively (table 2). Zika virus risk was the main reason for pretravel consultation in $4.5 \%$ of all travellers and $9.9 \%$ of travellers to LAC. About one-third of traveller's $(32.2 \%)$ had an airport stop-over in a country endemic for YF (commonly Brazil or Argentina); 26.6\% of trips included two or more regions (according to United Nations M49 Standard ${ }^{12}$ (table 2).

\section{Pretravel vaccination and malaria prevention}

The most commonly indicated vaccines were hepatitis A $(83.8 \%)$, YF $(57.5 \%)$ and typhoid fever $(50.9 \%)$, followed by rabies $(28.5 \%)$, measles $(20.9 \%)$, polio $(7.7 \%)$, Japanese encephalitis (JE) (6.4\%) and quadrivalent meningococcal vaccine $(5.1 \%)$ (table 2 ). Malaria prophylaxis and stand-by emergency treatment were recommended in $28.0 \%$ and $12.2 \%$ of travellers, respectively (table 2 ).

\section{Comparison of leisure and work-related travellers}

In contrast to leisure travellers, those travelling for workrelated reasons were predominantly male; they were also older and more often of non-Chilean nationality (table 3). Compared with leisure travel, work-related trips were more often very short (1-7 days) or very long (>90 days), more often included repeated travel activities, and were prepared with $<2$ weeks of predeparture time (table 3 ). Leisure trips were more commonly to less developed regions, especially in Africa. Accordingly, leisure travellers had a higher exposure risks for tropical infections and more frequent indications for hepatitis $\mathrm{A}$ vaccine and malaria chemoprophylaxis (table 3). Work-related trips were more often within America, mostly South and Central America (table 3, figure 1). Other regions with a higher rate of professional travel were Europe and SouthCentral Asia (figure 1). Due to the above mentioned differences, work-related travellers were more often in need of rabies, JE and meningococcal meningitis vaccine and had a higher level of complexity (tables 3 and 4).

\section{Complexity of travel consultations}

The criteria used to define different factors associated with a more complex pretravel consultation are summarised in table 1 . More than one-third of our population $(35.7 \%)$ consulted for prolonged ( $\geq 4$ weeks) or repeated travel to less developed regions. Other frequent factors of complexity were insufficient time to departure $(29.1 \%)$, travel reasons or activities with a higher risk of exposure to diseases transmitted by food or contact to the local population, vectors or animals, or with a higher risk of accidents or with inadequate medical support (13.4\%), and individuals with conditions that could cause complications related to travel or to travel-related vaccinations such as pregnancy, breast feeding, immunocompromise or other severe diseases or disabilities $(8.2 \%)$ (table 4 ). Most of the pregnancy-related questions $(74.1 \%)$ arose in travellers planning journeys within LAC. Due to the high demand of YF vaccine in our study population (57.5\%), situations requiring a careful assessment of the risk and benefit were relatively frequent, mainly related to the age of the traveller $(7.6 \%)$ or inadequate time $(<10$ days $)$ to departure $(7.8 \%)$. Those travellers, who visited three or more different regions $(6.0 \%)$, were also classified as complex (table 4). According to our complexity score, only $34.8 \%$ of consultations classified as uncomplicated. In $32.3 \%$ of travellers there was one, in $24.2 \%$ two, and in $8.8 \%$ three or more criteria of complexity (table 4 ). Overall, work-related travellers had higher complexity levels than leisure travellers, mainly due higher rates of prolonged travel to less developed regions and insufficient time for pretravel preparation and vaccination (table 4).

\section{DISCUSSION}

As in other emerging market countries, the number of Chilean travellers abroad has doubled over the last 10 years from 1.9 million in 2008 to 3.8 million in $2018 .^{19}$ Still, travel medicine remains a niche discipline and most medical providers and travellers in Chile are not aware of its existence. ${ }^{20} \mathrm{~A}$ similar knowledge gap has been reported in travellers from Asia, ${ }^{21}$ in contrast to studies from countries with a longer tradition of travels' health such as Germany, where $48 \%$ of travellers to South-East Asia had received professional pretravel advice. ${ }^{22}$ Deficits regarding travellers' health issues in Chile are extensive and include the infrastructure as well as the practical experience and training possibilities. Therefore, it is not surprising that Chile and other countries from Latin America contribute only marginally to the scientific literature regarding travel medicine,${ }^{23}$ and travellers from these countries and other less developed regions generally receive less professional pretravel advice and immunisations than those from Western countries. ${ }^{24-27}$

The practice of travel medicine in less developed regions should be adapted to the socioeconomic and other structural conditions of the respective cultural setting. ${ }^{25}$ Furthermore, the concept of travel medicine as 
Table 3 Comparison of selected characteristics of pretravel consultations of leisure and work-related travellers

\begin{tabular}{|c|c|c|c|c|c|c|c|}
\hline \multicolumn{3}{|l|}{ Characteristics } & \multicolumn{2}{|c|}{$\begin{array}{l}\text { Leisure travellers* } \\
(\mathrm{n}=1021)\end{array}$} & \multicolumn{2}{|c|}{$\begin{array}{l}\text { Work-related travellers } \dagger \\
(\mathrm{n}=311)\end{array}$} & \multirow{2}{*}{$\begin{array}{l}\text { P value } \\
<0.0001\end{array}$} \\
\hline \multirow[t]{3}{*}{ Traveller } & Sex & Male & 456 & $(44.7)$ & 189 & (60.8) & \\
\hline & & IQR & $26-4$ & & $28-4$ & & \\
\hline & Nationality & Chilean & 882 & $(86.4)$ & 247 & (79.4) & 0.003 \\
\hline & & $1-7$ days & 109 & $(10.7)$ & 87 & (28.2) & $<0.0001$ \\
\hline & & >90 days & 70 & $(6.9)$ & 134 & (43.5) & $<0.0001$ \\
\hline Repeated travel & & & 11 & $(1.1)$ & 68 & (21.9) & $<0.0001$ \\
\hline Time to departure & & Median & $28 d$ & & $23 d$ & & 0.03 \\
\hline & Asia & & 385 & $(37.7)$ & 102 & (32.8) & 0.12 \\
\hline & Africa & & 317 & (31.0) & 46 & (14.8) & $<0.0001$ \\
\hline & Oceania & & 54 & (5.3) & 22 & $(7.1)$ & 0.24 \\
\hline & Europe & & 45 & $(4.4)$ & 23 & (7.4) & 0.036 \\
\hline & Less develo & regionsł & 999 & $(97.8)$ & 274 & (88.1) & $<0.0001$ \\
\hline \multirow[t]{3}{*}{ Infection risk } & Dengue (tro & boviruses) & 987 & $(96.7)$ & 267 & (85.9) & $<0.0001$ \\
\hline & Malaria & & 781 & $(76.5)$ & 165 & (53.1) & $<0.0001$ \\
\hline & Yellow fever & & 348 & $(34.1)$ & 133 & $(42.8)$ & 0.005 \\
\hline & Japanese er & halitis & 55 & $(5.4)$ & 41 & (13.2) & $<0.0001$ \\
\hline & Meningococ & & 29 & $(2.8)$ & 44 & $(14.1)$ & $<0.0001$ \\
\hline \multirow[t]{3}{*}{ Complexity } & Score value & $=0$ & 397 & (38.9) & 64 & (20.6) & $<0.0001$ \\
\hline & & $=1$ & 322 & (31.5) & 108 & (34.7) & \\
\hline & & $>1$ & 302 & (29.6) & 139 & $(44.7)$ & \\
\hline
\end{tabular}

Values represent number (\%) of consultations, if not otherwise specified.

*Tourism, backpacking or adventure travel.

†Business or study.

$\ddagger$ According to United Nations classification. ${ }^{12}$

SIndication for vaccine or waiver letter.

'medical care for Western tourists' and other travellers' health limitations, which have been recognised in Asia but similarly exist in Latin America should be taken into consideration and modernised. ${ }^{28}$ As a first step to advance with the concept of 'travel medicine outside the Western hemisphere', traveller populations of less developed countries such as Chile have to be analysed and compared, in order to understand specific needs and differences.
A methodological limitation of the study was that it was unicentric and performed by a single travel medicine expert, although this improves data homogeneity.

The main demographic characteristics were similar to travel medicine centres in Europe and the USA. ${ }^{6929} \mathrm{~A}$ specific challenge was the considerable amount of foreign travellers seeking advice in our centre. This heterogeneous group required higher expertise due to the variable and 
Table 4 Characteristics related to complexity of pretravel consultations

\begin{tabular}{|c|c|c|c|c|c|c|c|}
\hline \multirow{2}{*}{$\begin{array}{l}\text { Characteristics }^{*} \\
\text { Long/repeated travel to less developed regions§ }\end{array}$} & \multicolumn{2}{|c|}{$\begin{array}{l}\text { All travellers } \\
(n=1341)\end{array}$} & \multicolumn{2}{|c|}{$\begin{array}{l}\text { Leisure travellers } \dagger \\
(n=1021)\end{array}$} & \multicolumn{2}{|c|}{$\begin{array}{l}\text { Work-related travellers } \neq \\
(\mathrm{n}=311)\end{array}$} & \multirow{2}{*}{$\frac{P \text { value }}{<0.0001}$} \\
\hline & 479 & (35.7) & 313 & (30.6) & 185 & (59.5) & \\
\hline Insufficient pre-travel time & 390 & (29.1) & 282 & $(27.6)$ & 108 & (34.7) & 0.016 \\
\hline High-risk travel type or activity & 180 & (13.4) & 108 & $(10.6)$ & 44 & $(14.1)$ & 0.083 \\
\hline High-risk traveller & 110 & (8.2) & 90 & (8.8) & 21 & (6.8) & 0.25 \\
\hline Pregnancy-related/breastfeeding & 54 & $(4.0)$ & 42 & $(4.1)$ & 12 & (3.9) & 0.84 \\
\hline Immunocompromised & 32 & (2.4) & 29 & (2.8) & 3 & (1.0) & 0.059 \\
\hline Other & 24 & (1.8) & 19 & (1.9) & 6 & (1.9) & 0.94 \\
\hline Insufficient time for YF vaccine & 105 & (7.8) & 66 & (6.5) & 32 & (10.3) & 0.024 \\
\hline$Y F$ vaccine in traveller $\geq 60$ years & 102 & (7.6) & 78 & (7.6) & 20 & (6.4) & 0.47 \\
\hline Visiting $\geq 3$ regions & 80 & (6.0) & 71 & (7.0) & 20 & (6.4) & 0.75 \\
\hline \multicolumn{8}{|l|}{ Complexity score values } \\
\hline 0 & 467 & (34.8) & 397 & (38.9) & 64 & $(20.6)$ & $<0.0001$ \\
\hline 1 & 432 & (32.2) & 322 & (31.5) & 108 & (34.7) & 0.29 \\
\hline 2 & 324 & (24.2) & 231 & (22.6) & 101 & (32.5) & 0.0004 \\
\hline$\geq 3$ & 118 & (8.8) & 71 & (7.0) & 38 & (12.2) & 0.003 \\
\hline
\end{tabular}

Values represent number (\%) of consultations.

${ }^{*}$ For details, see table 1.

†Tourism, backpacking or adventure travel.

‡Business or study.

$\S$ According to United Nations classification. ${ }^{12}$

YF, yellow fever.

often unknown vaccination status and possible language barriers.

As in similar analyses in industrialised countries, leisure was the predominating travel purpose. Professional travel activities accounted for almost one quarter of consultations, which was superior to most European studies. ${ }^{589}$ High rates of work-associated consultations are typical for settings with limited access to travel medicine, reflecting on a higher motivation of this group of travellers or their employers to seek advice. In a recent report from China, which has an extremely low density of travel medicine providers, over $90 \%$ of pretravel consultations were related to work-related trips. ${ }^{30}$ Professional travel activities were also predominating in Singapore $(77 \%)$ and Brazil $(51 \%) .{ }^{11}{ }^{31}$ For various reasons, health advice for workrelated travellers is often complex. ${ }^{32}$ In our study, this group presented with less anticipation than leisure travellers and more often travelled repeatedly or for prolonged periods. Due to their travel profile, work-related travellers were in higher need for less available travel vaccines such as rabies, JE and meningococcal vaccine and only $20.6 \%$ were classified simple consultations (table 4).

According to Chilean data from 2017, VFR travellers accounted for $14 \%$ of outbound travel. ${ }^{19}$ With $4.8 \%$, this group of travellers was underrepresented in our population, most probably due to limited access to private medicine services. In Dutch, Spanish and French studies, VFRs represented $17.3 \%, 16.1 \%$ and $13.5 \%$ of pretravel consultation, respectively, with lower rates in travel medicine centres in Switzerland $(7.8 \%)$ and Greece $(4 \%) \cdot{ }^{5-9}$ Since this group has a higher risk of travel-associated diseases, ${ }^{33}$ and the number of migrants in Chile is rapidly emerging, the implementation of travel medicine in Chile's public healthcare service is urgently needed.

The studied population visited a wide spectrum of itineraries. The distribution of destinations varied to reports from other countries. Compared with Europe and the USA, more travelled within South America, but less to African regions. ${ }^{6729}$ South-East Asia was a frequent destination for tourists, for example, visited by $>50 \%$ of the honeymooners of the study. The increasing popularity of Asian travel destinations is in accordance with observations from Europe. ${ }^{10} 34$

The vast majority of the study population visited less developed countries, mostly located in tropical regions. Thus, almost all consultations included detailed information on mosquito prevention. The use of adequate skin repellents is Chile has been complicated by the limited availability of effective products. A high percentage $(37 \%)$ of travellers visited regions in LAC with ongoing Zika virus risk and required detailed information regarding exposure, sexual transmission and precautions regarding pregnancy or planned pregnancy. In 4.5\%, Zika virus was the main reason for consultation, often resulting in a change of holiday or work plans; these travellers were provided with medical certificates for airlines, travel agencies or employers. More than two-thirds of the consultations included advice regarding malaria risk. The majority 
visited low to intermediate risk areas in LAC or Asia. Since national (Chilean) or regional (South American) guidelines for malaria prevention in travellers are lacking and international recommendations are non-uniform, decisions have to be made on an individual basis and require adequate training and experience. Although not systematically studied here, the most commonly used antimalarial drug for both prophylaxis and stand-by emergency treatment was atovaquone/proguanil (Malarone).

In accordance to reports from other countries, hepatitis $\mathrm{A}$ and typhoid fever vaccines were commonly indicated vaccines. ${ }^{67102935}$ The use of hepatitis A vaccination in Chile is complicated by the lack of epidemiological data and of national recommendations for different age groups. The author's individual practice was to generally vaccinate those born during or after the 1970s and older travellers depending on disease history and preference. Notably, $58 \%$ of our travellers had an indication for YF vaccination, compared with $8.9 \%$ in Sweden or $22 \%$ in Switzerland. ${ }^{810}$ A specific problem for Chilean travellers is that many international flights have stopovers in Brazil or other YF endemic countries. Although those transits are not considered a medical indication for $\mathrm{YF}$ vaccination, travellers might require the vaccine to enter their final destination in Asian or African countries. In recent years, many (but not all) of these countries have exempted travellers if airport transit is $<12$ hours. Unfortunately, this '12-hour rule' has some pitfalls. Some countries do not apply it in a consistent way and, in addition, it is sensible to flight delays (resulting in stopovers $>12$ hours). Therefore, many Chilean travellers opt to get vaccinated to avoid complications and also for future travels within South America. Boosted by the recent outbreak in Brazil, YF vaccine-related questions are currently a main challenge for physicians providing travel medicine advice in Chile. ${ }^{36}$ Routine questions and challenges regarding this situation were recently addressed by practice guideline for Chilean physicians. ${ }^{37}$ The use of vaccines for low incidence/high impact diseases such as rabies, JE and meningococcal meningitis requires advanced epidemiological information and knowledge in travel medicine, especially in countries without national travel medicine guidelines. Rabies vaccination was indicated in $28.5 \%$ of our population, a much higher rate than reported in centres in Europe and the USA. ${ }^{6} 102935$ This difference most probably reflects on our travellers' high rate $(35.7 \%)$ of prolonged trips to less developed regions (table 4). The indication for $\mathrm{JE}$ vaccination, defined as stays in rural endemic regions of $>4$ weeks or any endemic area $>3$ months, was present in $6.4 \%$ of travellers. This is significantly higher than the rates reported from mot travel clinics in Europe. ${ }^{6-9} 35$ Since this vaccine is unavailable in Chile, travellers were advised to obtain it abroad and were provided with information, where to access it. A major problem providing adequate pretravel advice during the study period was the erratic availability of vaccines and antimalarial drugs. This included the temporary absence of vaccines for hepatitis A, typhoid fever, rabies, polio and YF. The access to travel vaccines in Chile is further complicated by regulatory issues, since vaccines are mostly provided in public vaccination centres, not authorised to apply vaccines for travelrelated indications (eg, rabies, polio, MMR). Similar problems have been reported from countries in Asia. ${ }^{28}$

To quantify the above-mentioned challenges of our population, we applied a 'complexity score'. This score combined different criteria, which are related to 'difficulty' and necessary level of experience in travel medicine. The objective of this scoring was to reach a more comprehensive description of the population and to permit a comparison to travellers from other centres. Such analysis is also useful to estimate the required level of training and expertise of the personnel. In our population, about one-third of visits were considered 'routine' travel medicine consultations, while two-thirds were classified as complex or very complex. This relatively high level of complexity within our population was supported by the high need of travel-specific vaccines in comparison with European studies (see above). Multiple reasons might contribute for this complexity of travel medicine in emerging countries such as Chile. First, international trips are much less accessible and more expensive; thus, travellers tend to cover multiple regions and travel for prolonged times. The mean and median periods of leisure travel to Asia in our population, for example, were 75 and 28 days, respectively. Second, due to the relevant costs of travellers' health services including vaccines, advice might preferentially be sought for larger and more complex journeys. As mentioned above, travel medicine is rather unknown and not considered a routine preventive medicine service. A third factor more specific to the localisation of Chile was the high percentage of problems regarding $\mathrm{YF}$ vaccination as mentioned above.

\section{CONCLUSIONS}

This descriptive study contributes to our knowledge of the situation and problems of travel medicine in less developed regions. The traveller population was diverse and mostly visited less developed and tropical regions, resulting in a high level of complexity of travellers' health issues. Thus, most consultations required a comprehensive knowledge in travel medicine. There was a higher need of YF and other travel-related vaccines than reported from other countries, which is a major challenge in countries of limited and unstable vaccine supplies. The lack of national guidelines, specialised institutions, and training opportunities might contribute to discrepancies between the standards defined by experts from industrialised regions and the reality of travel medicine in less developed nations.

Acknowledgements I thank Soledad Elias, Paula Araya and the other personnel of the Travel Medicine Program at Clínica Alemana for their support, and Gerardo Acosta-Jamett for his critical review of the presentation and analysis of data. Parts of the study have been presented at the 6th Conference of the International Society of Travel Medicine, Washington, USA, 5-9th of June 2019, and the XXXIV Congreso Chileno de Infectología, 8-11 November 2017, Concepción, Chile. 
Contributors TW conceived and planned the study, collected and analysed the data and wrote the manuscript.

Funding The authors have not declared a specific grant for this research from any funding agency in the public, commercial or not-for-profit sectors.

Map disclaimer The depiction of boundaries on this map does not imply the expression of any opinion whatsoever on the part of BMJ (or any member of its group) concerning the legal status of any country, territory, jurisdiction or area or of its authorities. This map is provided without any warranty of any kind, either express or implied.

\section{Competing interests None declared.}

Patient and public involvement Patients and/or the public were not involved in the design, or conduct, or reporting, or dissemination plans of this research.

\section{Patient consent for publication Not required.}

Ethics approval The study was approved by the Institutional Review Board of the Medical Faculty Clínica Alemana, Universidad del Desarrollo, Santiago, Chile (Comité Ético Científico, no 2013-13).

Provenance and peer review Not commissioned; externally peer reviewed.

Data availability statement Data are available on reasonable request. The anonymous data set is held with the PI, TW. Any request to access the data should be made to thomas.weitzel@gmail.com and will be considered.

Open access This is an open access article distributed in accordance with the Creative Commons Attribution Non Commercial (CC BY-NC 4.0) license, which permits others to distribute, remix, adapt, build upon this work non-commercially, and license their derivative works on different terms, provided the original work is properly cited, appropriate credit is given, any changes made indicated, and the use is non-commercial. See: http://creativecommons.org/licenses/by-nc/4.0/.

\section{ORCID iD}

Thomas Weitzel http://orcid.org/0000-0002-9804-2123

\section{REFERENCES}

1 Buck G, Steffen R. History of the development of Travel Medicine as a new discipline. In: Wilder-Smith A, Schwartz E, Shawn M, eds Travel medicine - tales behind the science. Oxford - Amsterdam: Elsevier, 2007: 71-2.

2 Glaesser D, Kester J, Paulose H, et al. Global travel patterns: an overview. J Travel Med 2017;24:tax007.

3 Wilder-Smith A. Closing the gap in travel medicine. J Travel Med 2017;24.

4 Chen LH, Leder K, Wilson ME. Closing the gap in travel medicine: reframing research questions for a new era. $J$ Travel Med 2017;24:tax001.

5 Valerio L, Martínez O, Sabrià M, et al. High-Risk travel abroad overtook low-risk travel from 1999 to 2004: characterization and trends in 2,622 Spanish travelers. J Travel Med 2005;12:327-31.

6 Aubry C, Gaudart J, Gaillard C, et al. Demographics, health and travel characteristics of international travellers at a pre-travel clinic in Marseille, France. Travel Med Infect Dis 2012;10:247-56.

7 Pavli A, Spilioti A, Lymperi I, et al. Vaccinations for international travellers travelling from Greece. Travel Med Infect Dis 2013;11:225-30.

8 Bühler S, Rüegg R, Steffen R, et al. A profile of travelers--an analysis from a large swiss travel clinic. J Travel Med 2014;21:324-31.

9 Wieten RW, van der Schalie M, Visser BJ, et al. Risk factors and pre-travel healthcare of international travellers attending a Dutch travel clinic: a cross-sectional analysis. Travel Med Infect Dis 2014;12:511-24.

10 Angelin $\mathrm{M}$, Evengård $\mathrm{B}$, Palmgren $\mathrm{H}$. Travel and vaccination patterns: a report from a travel medicine clinic in northern Sweden. Scand J Infect Dis 2011;43:714-20.

11 SC L, Mascheretti M, Chaves TSS, et al. Vacinação DOS viajantes: experiencia do ambulatório DOS viajantes do Hospital das clínicas dA faculdade de medicina dA universidade de São Paulo. Rev Soc Bras Med Trop 2008;41:474-8.

12 United Nations Department of Economic and Social Affairs. Standard country or area codes for statistical use (M49). Available: https:// unstats.un.org/unsd/methodology/m49
13 CDC. Yellow book, 2020. Available: wwwnc.cdc.gov/travel/page/ yellowbook-home [Accessed 15 Feb 2020].

14 Hill DR, Ericsson CD, Pearson RD, et al. The practice of travel medicine: guidelines by the infectious diseases Society of America. Clin Infect Dis 2006;43:1499-539.

15 Rothe C, Alberer M, Bühler S, et al. Reiseimpfungen - Hinweise und Empfehlungen. Flug u Reisemed 2019;26:58-79.

16 Ministerio de Salud. Recomendaciones Contra El Sarampión. Available: www.minsal.cl/recomendaciones-de-vacunacion-aviajeros/sarampion [Accessed 15 Feb 2020].

17 Rothe C, Boecken G, Rosenbusch D, et al. Empfehlungen Zur Malariaprophylaxe. Flug u Reisemed 2019;26:105-32.

18 PHE Advisory Committee on Malaria Prevention. Malaria prevention guidelines for travellers from the UK. Available: www.gov.uk/ government/publications/malaria-prevention-guidelines-fortravellers-from-the-uk [Accessed 15 Feb 2020].

19 Subsecretaría de Turismo. Turismo Emisivo. Available: http://www. subturismo.gob.cl/turismo-emisivo [Accessed 15 Feb 2020].

20 Guerrero-Lillo L, Medrano-Díaz J, Pérez C, et al. Knowledge, attitudes, and practices evaluation about travel medicine in international travelers and medical students in Chile. J Travel Med 2009;16:60-3.

21 Hung KKC, Lin AKY, Cheng CKY, et al. Travel health risk perceptions and preparations among travelers at Hong Kong International Airport. J Travel Med 2014;21:288-91.

22 Rolling T, Mühlenpfordt M, Addo MM, et al. Pre-travel advice at a crossroad: Medical preparedness of travellers to South and Southeast-Asia - The Hamburg Airport Survey. Travel Med Infect Dis 2017;18:41-5.

23 Leong WY. Monitoring 'Closing the Gap in Travel Medicine': need to focus on Africa and Latin America. J Travel Med 2019;26:tay149.

24 Wilder-Smith A, Khairullah NS, Song J-H, et al. Travel health knowledge, attitudes and practices among Australasian travelers. $J$ Travel Med 2004;11:9-15.

25 Piyaphanee W, Steffen R, Shlim DR, et al. Travel medicine for Asian travelers--do we need new approaches? J Travel Med 2012;19:335-7.

26 Heywood AE, Watkins RE, lamsirithaworn S, et al. A cross-sectional study of pre-travel health-seeking practices among travelers departing Sydney and Bangkok airports. BMC Public Health 2012;12:321.

27 Olanwijitwong J, Piyaphanee W, Poovorawan K, et al. Health problems among Thai tourists returning from India. $J$ Travel Med 2017;24:tax013.

28 Leder K, Borwein S, Chanthavanich P, et al. Travel medicine perspectives of select travel medicine experts practicing in the AsiaPacific region. J Travel Med 2017;24:tax012.

29 LaRocque RC, Rao SR, Lee J, et al. Global TravEpiNet: a national consortium of clinics providing care to international travelers-analysis of demographic characteristics, travel destinations, and pretravel healthcare of high-risk US international travelers, 20092011. Clin Infect Dis 2012;54:455-62.

30 Zhang M, Zhang J, Hao Y, et al. Vaccination knowledge, attitude and practice among Chinese travelers who visit travel clinics in preparation for international travel. J Travel Med 2016;23:taw051.

31 Lee VJ, Wilder-Smith A. Travel characteristics and health practices among travellers at the travellers' health and vaccination clinic in Singapore. Ann Acad Med Singapore 2006;35:667-73.

32 Bunn WB, Johnson CE, et al. The Business Traveler. In: Keystone J, Kozarsky P, Connor B, et al, eds. Travel medicine. 4th Edition. Oxford - Amsterdam: Elsevier, 2018: 287-93.

33 Heywood AE, Zwar N. Improving access and provision of pre-travel healthcare for travellers visiting friends and relatives: a review of the evidence†. J Travel Med 2018;25.

34 Segura M, Lopez-Gigosos R, Mariscal-Lopez E, et al. Trends in the travelers' demand for pre-travel medical advice at a Spanish international vaccination center between 2000 and 2017. PLoS One 2019;14:e0217588.

35 Troiano G, Mercone A, Bagnoli A, et al. International travelers' sociodemographic, health, and travel characteristics: an Italian study Ann Glob Health 2017:83:380-5.

36 Weitzel T, Vial P, Perret C, et al. Shortage of yellow fever vaccination: a travel medicine emergency for Chilean travellers. Travel Med Infect Dis 2019;28:1-2.

37 Weitzel T, Perret C, Valdivieso F, et al. Yellow fever vaccination for Chilean tourists visiting Brazil. practical considerations. Rev Chilena Infectol 2018;35:587-90. 